\title{
Disease associated with integumentary and cloacal parasites in tadpoles of northern red-legged frog Rana aurora aurora
}

\author{
Nathan C. Nieto ${ }^{1,3, *}$, Michael A. Camann ${ }^{1}$, Janet E. Foley ${ }^{2}$, John O. Reiss ${ }^{1}$ \\ ${ }^{1}$ Department of Biological Sciences, Humboldt State University, Arcata, California 95521, USA \\ ${ }^{2}$ Department of Veterinary Medicine and Epidemiology, University of California, Davis, California 95616, USA \\ ${ }^{3}$ Present address: 1320 Tupper Hall, Department of Veterinary Medicine and Epidemiology, University of California, Davis, \\ California 95616, USA
}

\begin{abstract}
A total of 6830 northern red-legged frog Rana aurora aurora tadpoles were examined under a dissecting microscope for oral disc, integumentary, and cloacal abnormalities in 13 ponds in and near Redwood National Park in northern California. Of these, 163 tadpoles were collected for histopathological investigation, including 115 randomly collected individuals, 38 collected with oral disc abnormalities, and 10 collected due to severe morbidity of unknown etiology. The tadpoles were infected with 8 parasites, including Batrachochytrium dendrobatidis (the amphibian chytrid), trematodes, leeches, and protozoa. Chytridiomycosis was detected at an overall prevalence of $6.4 \%$, but prevalence was higher in tadpoles with oral disc lesions than in those with normal oral discs $(43.5 \%$ versus $6.1 \%$ ). Interestingly, infection was associated with some environmental and co-infection risk factors. Individual tadpoles possessed 0 to 5 species of parasites in varying intensities. Apiosoma sp. was the most prevalent (66\%) and widespread. Tadpoles infected with $B$. dendrobatidis had a lower diversity of oral parasites than those uninfected. During the field portion of the study, a large number $(\sim 500)$ of moribund and dead tadpoles was seen occurring at multiple locations within and surrounding Redwood National Park. Ten animals were collected for histological examination and a diverse protozoal infection was discovered, including some known pathogens of fish. This study is the first reporting parasitism and disease in natural populations of northern red-legged frogs.
\end{abstract}

KEY WORDS: Chytridiomycosis · Parasite diversity · Protozoal parasites · Tadpoles · Unusual morbidity

Resale or republication not permitted without written consent of the publisher

\section{INTRODUCTION}

A number of newly identified diseases has been associated with amphibian declines (Daszak et al. 1999). An iridovirus infection caused die-offs of tiger salamanders Ambystoma tigrinum and wood frogs Rana sylvatica across North America, while chytridiomycosis (caused by Batrachochytrium dendrobatidis) was responsible for die-offs of endangered leopard frogs ( $R$. yavapaiensis, $R$. chiricahuensis), mountain yellow-legged frogs $R$. muscosa and Wyoming toads Bufo baxteri (Bollinger et al. 1999, Fellers et al. 2001, Bradley et al. 2002, Green et al. 2002, Carey et al.
2003). Chytridiomycosis in particular causes mortality in a large number of amphibian species and has been implicated as a primary cause of amphibian population declines around the world (Berger et al. 1998). Additionally, in the western USA an increase in the number of malformed amphibians has been linked to the presence of the trematode Ribeiroia ondatrae, although population declines were not addressed (Johnson et al. 2002). Wide-scale amphibian decline is likely due to a complex synergism of factors including climate change, environmental pollution and degradation, and the presence of virulent pathogens and parasites (Young et al. 2001, Kiesecker 2002, Pahkala et al. 2002, 
Blaustein \& Johnson 2003). The involvement of synergistic influences underscores the importance of simultaneously evaluating multiple contributors to amphibian declines.

One species of frog that may be particularly susceptible to disease is the red-legged frog Rana aurora. This species is subdivided into a northern subspecies, the northern red-legged frog $R$. aurora aurora, and a southern subspecies, the California red-legged frog $R$. aurora draytonii. The northern subspecies occurs from southern Canada southward to northern California, while the southern subspecies occurs in isolated populations throughout California south of the northern subspecies (Stebbins 2003). Both subspecies occur sympatrically in northern coastal California (Mendocino County, California). The southern subspecies has suffered a severe population decline resulting in a much more restricted range (Davidson et al. 2001). A number of studies have analyzed the effects of pesticide drift, introduced predators, habitat loss, and UV-B radiation damage on $R$. aurora populations (Blaustein et al. 1994, Davidson et al. 2001, 2002). However, little is known about the natural diversity of microbial and metazoan parasites in apparently healthy $R$. aurora populations and possible influences such parasites might have on larval health and population stability.

The tadpole life-stage of frogs is vulnerable to a number of specific diseases caused by infectious microorganisms and metazoan parasites (Green 2001). High rates of mortality of amphibian larvae are common in North America except in some stream-inhabiting salamanders (Duellman \& Trueb 1986). R. aurora tadpole survival is typically low in wild populations $(<10 \%)$ and is not considered a primary influence on population persistence (Licht 1971, Calef 1973). In one study, $91 \%$ of red-legged frog embryos survived to become larvae while only $5 \%$ of larvae survived through metamorphosis (Licht 1971). However, environmental and infectious stressors experienced by larvae can lead to increased levels of mortality in adult frogs, possibly contributing to population declines. In particular, larval physical condition influences survival to adulthood (Goater 1994, Goater \& Vandenbos 1997). During metamorphosis, tadpoles subsist using energy stored in tail muscle and fat bodies; larger larval toads and wood frogs have a higher probability of survival through metamorphosis than smaller individuals (Goater 1994, Goater \& Vandenbos 1997). Parasitism in tadpoles may decrease available energy, result in smaller individuals at metamorphosis and reduce survival in the wild (Parris \& Baud 2004).

The primary goals of the present study were to (1) estimate the prevalence of Batrachochytrium dendrobatidis (a virulent pathogen of amphibians) in larval northern red-legged frog buccal cavities in far north- coastal California, (2) describe the rest of the parasite community of the frog, (3) characterize abundance of parasites associated with integumentary and cloacal infections, (4) investigate differences in disease prevalence and intensity of parasite infection between frogs from lotic and lentic breeding habitats, and (5) report on a mass morbidity and mortality event that occurred in 2001-2002. Study populations were within and around Redwood National Park, a site approximately $400 \mathrm{~km}$ north of the zone of intergradation between northern and California subspecies of Rana aurora. The associations of parasitism with clinical disease in frog larvae and differences in disease manifestation and parasite intensity between habitat types provide valuable information for an eventual understanding of possible sources of morbidity and mortality in $R$. aurora and declines in highly vulnerable populations.

\section{MATERIALS AND METHODS}

Study sites. Thirteen permanent ponds in and adjacent to Redwood National Park, Del Norte and Humboldt Counties, California, USA were surveyed during spring (the red-legged frog breeding season) in 2001 and 2002 (Table 1). The entire park is located in the coastal fog belt of northern California, with an elevation from 0 to $670 \mathrm{~m}$. The park receives an annual average of $1679 \mathrm{~mm}$ of precipitation in the form of rain in the winter months (October to April) and dense coastal fog in summer. The average daily temperature varies only slightly from summer to winter, with a mean annual temperature of $15^{\circ} \mathrm{C}$ (Noss 2000). In addition to northern red-legged frogs Rana aurora aurora, the study sites host a diversity of other breeding amphibians (Hyla regilla, R. catesbeiana, Taricha granulosa, Ambystoma gracile, and Dicamptodon tenebrosus), fishes (mostly three-spine sticklebacks Gasterostelus aculeatus) and numerous aquatic invertebrates.

Eight sites were located within the park boundary and 5 were distributed north and south of the park boundary (Table 1). The sites within the park had varying degrees of anthropogenic influence, ranging from ponds adjacent to Highway 101 and the Redwood National Park Visitors' Center to 3 sites that cannot be reached with a vehicle. The sites outside the park tended to have a higher level and more diverse array of anthropogenic impacts, including car camping sites and freeway vistas; there were also sites in protected reserves. All study sites were separated by at least 2 $\mathrm{km}$ (slightly more than the maximum distance an adult red-legged frog is able to travel, based on radio telemetry; Chan-McLeod 2003) to minimize the likelihood of transmission of disease agents between sites during the study. All sites were $<100 \mathrm{~m}$ in elevation. 
Table 1. Rana aurora aurora. Parasite study site locations from within and around Redwood National Park. Year 1: 2001; Year 2: 2002

\begin{tabular}{|c|c|c|c|c|c|c|}
\hline $\begin{array}{l}\text { Identity } \\
\text { code }\end{array}$ & $\begin{array}{l}\text { Within or } \\
\text { outside park } \\
\text { boundary }\end{array}$ & Lat./Long. & $\begin{array}{l}\text { Lentic or } \\
\text { lotic habitat }\end{array}$ & $\begin{array}{l}\text { Mean depth } \\
(\mathrm{m})\end{array}$ & $\begin{array}{c}\text { Years } \\
\text { sampled }\end{array}$ & Notes \\
\hline DELA & Out & $\begin{array}{c}41^{\circ} 47^{\prime} 18^{\prime \prime} \mathrm{N} \\
124^{\circ} 13^{\prime} 46^{\prime \prime} \mathrm{W}\end{array}$ & Lentic & 0.4 & 1 and 2 & Near road, high recreation use \\
\hline URCR & In & $\begin{array}{c}41^{\circ} 16^{\prime} 50^{\prime \prime} \mathrm{N} \\
124^{\circ} 01^{\prime} 51^{\prime \prime} \mathrm{W}\end{array}$ & Lentic & 0.8 & 1 & No road access, near hiking trail \\
\hline ENBE & In & $\begin{array}{c}41^{\circ} 42^{\prime} 04^{\prime \prime} \mathrm{N} \\
124^{\circ} 08^{\prime} 31^{\prime \prime} \mathrm{W}\end{array}$ & Lotic & 0.6 & 1 and 2 & Tourist rest area, parking lot, picnic site \\
\hline OSTR & In & $\begin{array}{c}41^{\circ} 26^{\prime} 26^{\prime \prime} \mathrm{N} \\
124^{\circ} 03^{\prime} 43^{\prime \prime} \mathrm{W}\end{array}$ & Lotic & 0.3 & 1 and 2 & Low impact camping, low recreation, no road access \\
\hline DATR & In & $\begin{array}{c}41^{\circ} 19^{\prime} 12^{\prime \prime} \mathrm{N} \\
124^{\circ} 02^{\prime} 29^{\prime \prime} \mathrm{W}\end{array}$ & Lotic & 1.5 & 1 and 2 & Restoration site, high recreation use \\
\hline RDCR & In & $\begin{array}{c}41^{\circ} 17^{\prime} 19^{\prime \prime} \mathrm{N} \\
124^{\circ} 05^{\prime} 26^{\prime \prime} \mathrm{W}\end{array}$ & Lotic & 2.0 & 1 and 2 & Near visitors' center but low recreation use \\
\hline DRLA & In & $\begin{array}{c}41^{\circ} 13^{\prime} 26^{\prime \prime} \mathrm{N} \\
124^{\circ} 06^{\prime} 13^{\prime \prime} \mathrm{W}\end{array}$ & Lentic & 1.2 & 1 and 2 & Rest area, high recreation use \\
\hline CLBE & Out & $\begin{array}{c}40^{\circ} 59^{\prime} 37^{\prime \prime} \mathrm{N} \\
124^{\circ} 06^{\prime} 41^{\prime \prime} \mathrm{W}\end{array}$ & Lotic & 1 & 1 and 2 & Artificial pond near highway and airport \\
\hline CORE & Out & $\begin{array}{c}40^{\circ} 41^{\prime} 46^{\prime \prime} \mathrm{N} \\
124^{\circ} 14^{\prime} 42^{\prime \prime} \mathrm{W}\end{array}$ & Lentic & 0.5 & 1 and 2 & Artificial pond, high impact \\
\hline
\end{tabular}

Six lentic sites and 6 lotic sites were sampled in 2001; 4 lentic and 7 lotic sites were sampled in 2002. Lentic sites were those with some degree of flow in and out of the main body of water, while lotic sites had no water flow through the body of water.

Physical examination and tissue processing. At each pond, the first 300 Rana aurora aurora tadpoles observed were collected, anesthetized by immersion in MS-222 (tricaine methanesulfonate, Sigma), and thoroughly examined under a dissecting microscope for gross pathological abnormalities. However in year 2, fewer than 300 tadpoles could be found in 4 of the ponds. Normal tadpoles have a darkly pigmented oral disc. Therefore, tadpoles with depigmented patches on their oral discs were considered abnormal and potentially infected by Batrachochytrium dendrobatidis; all were collected. All other grossly abnormal individuals and 5 normal-appearing, randomly chosen individuals were retained for histological examination of the anterior head and oral disc. Each tadpole was euthanized by an overdose with $0.5 \%$ MS-222 and then fixed whole in $10 \%$ neutral buffered formalin by intracoelomic injection and immersion. All other individuals were returned to the ponds where they had been captured.
In order to ensure that there was no transport of disease between watersheds by the researchers, all field equipment was placed in plastic bags after use, sterilized by soaking in concentrated bleach solution ( $>1: 16)$ for over 3 min and air-dried (Fellers et al. 2001). Sample areas monitored in the same day were sampled using separate sets of equipment. All animal handling protocols were approved by the Humboldt State University Institutional Animal Care and Use Committee and animals were collected under California Department of Fish and Game and National Park Service scientific collection permits.

Of tadpoles retained for further examination, measurements included weight, total length, body length, tail length, tail-muscle width and tail-muscle height determined with a digital balance and calipers to $0.01 \mathrm{~g}$ and $0.1 \mathrm{~mm}$ accuracy, respectively. Interorbital distance and internarial distance were measured with calipers. The rostral head was dissected from the body and prepared for histological examination following standard techniques (Berger et al. 1998). Tissues were paraffin-embedded, sectioned at $8 \mu \mathrm{m}$, stained with hematoxylin and eosin (H\&E) or periodic acid-Schiff (PAS) stains (Humason 1979) and examined at 100×, 
400 $\times$, and 1000× magnifications using a compound microscope (Nikon Eclipse E400). The anterior skull and buccal cavity of each tadpole was serially sectioned. Representative sections were photographed through the light microscope.

For tadpoles with gross integumentary or cloacal lesions, further observations were made and additional samples collected in the field. Pale white, granular integumentary lesions were examined under the dissecting microscope to identify a typical trematodeassociated cyst. Representative cyst-containing sections were collected and fully dissected to reveal the organisms within. Cloacal abnormalities consisting of a cottony, white material extending from the cloacal orifice were observed in a number of tadpoles. The entire cloacas from 3 affected animals were removed by dissection, fixed in phosphate-buffered $2.5 \%$ glutaraldehyde ( $\mathrm{pH}$ 7.4), dehydrated, sputter-coated and examined with a scanning electron microscope (SEM, TopCon model ABT 32 WETSEM).

Identification and quantification of parasites. All parasites visible on histological examination of buccal cavities were counted. Fungi of the buccal cavity and cloacal protozoans were scored on a presence/absence basis only due to their high abundances when identified. Parasites were identified using standard texts on parasitology and amphibian medicine (Hoffman 1999, Wright \& Whittaker 2001). The location of infection, relative proportion of epithelial surface affected, and any other observable lesions were described. Intensity of parasitism was quantified as total numbers of parasites observed per individual calculated separately for each protozoan and metazoan parasite taxon. Ten randomly chosen individuals were collected at the Endert's Beach (ENBE) site in June 2002, euthanized as above and samples of liver and rostral heads were collected for histology. Five of these livers were prepared for transmission electron microscopic (TEM; Phillips EM208S) identification of possible viral particles.

Statistical analysis. The prevalence of Batrachochytrium dendrobatidis was calculated separately for larvae collected randomly and those collected because of the presence of oral disc abnormalities. All prevalence estimates for each parasite species were calculated as the percentage of the total sample found infected with the parasite. The parasite community was summarized using descriptive statistics. Ninetyfive percent confidence intervals (CI) for prevalence were calculated using the function 'prop.test' in the $\mathrm{R}$ software package (R-Development Core Team, www.r-project.org). A repeated-measures ANOVA was used to compare parasite intensities and prevalence of characteristic morbidity between lentic and lotic habitats and between years of the study using SAS statistical software (SAS Institute, 2001 version).
When needed, data were arcsine transformed to achieve normality. For metazoan parasites, the $k$ statistic was calculated to describe the degree to which metazoan parasites had an aggregated distribution within the buccal cavity (Shaw et al. 1998). The ability to predict chytridiomycosis in a pond or in an individual tadpole was tested using logistic regression and the calculation of odds ratios using the $\mathrm{R}$ package. Student's $t$-tests were used to compare mean pond depths of tadpoles with and without chytridiomycosis. Additionally, to test the hypothesis that chytridiomycosisinfected and uninfected individuals have different diversities or abundances of parasites, parasite species richnesses and Brillouin diversity indices (Krebs 1999) were compared using Wilcoxon rank sum tests. The abundance of each parasite taxon was also compared between infected and uninfected tadpoles using the Wilcoxon rank sum test to determine whether chytridiomycosis infection influences (1) the overall degree of parasitism or (2) that of each individual parasite taxon.

\section{RESULTS}

\section{Collection of tadpoles and gross pathological observations}

A total of 6830 tadpoles was examined for oral disc, integumentary and cloacal abnormalities. Of these, a total of 163 tadpoles was collected for histopathological investigation, including 115 randomly selected individuals, $38(0.6 \%, 95 \% \mathrm{CI}=0.4-0.8 \%)$ collected with oral disc abnormalities, and 10 collected because of their severe morbidity of unknown etiology.

Oral disc abnormalities were found in $67 \%$ of sites in the first year and $73 \%$ of sites the second year; prevalence ranged from 0 to $1.3 \%$ across sites throughout the study. The abnormalities varied from oral discs that were darkly (black) pigmented but asymmetrical to less pigmented (brown) to completely depigmented (white). Depigmentation ranged from $<10 \%$ to $100 \%$ loss of keratin pigment. Depigmented areas occurred both as general and localized disturbances on the leading edges of the beaks, margin of the beaks and epidermis and the toothrows. Depigmentation of the anterior beak was seen most often (67\%), while abnormalities of the toothrows (49\%) and posterior beak (8\%) were less common. In cases where toothrows were affected, some tadpoles exhibited a complete loss of toothrows, others loss of toothrows on one side, loss of individual teeth, or other asymmetry. The toothrow asymmetry included abnormal toothrow formulae or extra teeth developed individually on oral papillae. Most of the animals with abnormal mouthparts showed no other grossly visible pathological signs. 
Of the 163 tadpoles collected, 77 (47\%, 95\% CI = $39-55 \%$ ) tadpoles had thin, white uniform filamentous material extruding up to $0.5 \mathrm{~mm}$ from the cloaca; the cloacal mucosa and surrounding skin showed no abnormalities. Eleven $(6.7 \%, 95 \% \mathrm{CI}=3.5-12 \%)$ of the 163 tadpoles collected had cysts appearing as whitish granules underneath the epidermis. The cysts most often occurred in the caudal abdomen in the vicinity of the limb buds; however, other areas of the abdomen were also infested.

As an unexpected result of examining parasite diversity and parasitism intensity on tadpoles, we encountered a number of mass mortality events of unknown etiology at relatively widespread locations throughout Redwood National Park and its surroundings (Table 2). Moribund animals with subdermal gas, excessive iridescence and fragile skin were found at $58 \%$ of sites in 2001 and $73 \%$ in 2002. Every site with moribund tadpoles in 2001 that was re-sampled in 2002 had a repeat outbreak, and in year 2 additional locations (DELA, RDCR) had tadpole populations with signs of extensive morbidity. At locations with moribund animals, prevalence of characteristic morbidity ranged from 0.3 to $89 \%$, with a total mean prevalence of $13.4 \%$. There was a significantly higher prevalence of morbidity in lotic habitats (mean lentic $=7.0 \%$, mean lotic $=20.9 \%, p=0.01$, but no significant difference between years of the study (mean in $2001=12.8 \%$, mean in $2002=17.9 \%, p=$ 0.35). All of these sites had larvae of other species of amphibians (Hyla regilla, Ambystoma gracile, Taricha granulosa) present, none of which showed any signs of morbidity.

There was a characteristic clinical and pathological presentation in tadpoles involved in the mass morbidity events. Hundreds of dead and moribund tadpoles were seen floating on the water surface, while moribund animals were observed swimming abnormally and displaying lesions similar to those of dead tadpoles. Cellular exudates (pus) were commonly observed in the abdomen, and less commonly at other anatomical sites, including between the orbits and nares. In some cases, this lesion was localized medially to the orbits and nares. The epidermis was fragile to touch in many tadpoles and often the abdominal wall burst when handled, expelling the viscera. A large majority of the moribund animals had normally developed keratinized oral discs and well developed hindlimbs. Upon dissection of 10 moribund tadpoles, the external epithelium, visceral epithelium and much of the viscera appeared black and fragile (tore easily), in contrast to the normal larval viscera, which had

Table 2. Rana aurora aurora. Prevalence (\%) of parasites identified infesting tadpoles from each study site sampled. See Table 1 for site codes. Years are 2001 or 2002. Morbidity estimated from a sample of 300 tadpoles. Batrachochytrium dendrobatidis prevalence estimated separately for abnormal (left column) and randomly collected (right column) tadpoles

\begin{tabular}{|c|c|c|c|c|c|c|c|c|c|c|}
\hline Sites/Year & $\begin{array}{l}\text { Morbi- } \\
\text { dity }\end{array}$ & $\begin{array}{l}\text { Batracho } \\
\text { dendrc }\end{array}$ & $\begin{array}{l}\text { chytrium } \\
\text { batidis }\end{array}$ & Epistylis & Apiosoma & Ichthyobodo & Trichodina & $\begin{array}{l}\text { Gyrodactylus } \\
\text { aurorae }\end{array}$ & $\begin{array}{l}\text { Ribeirioia } \\
\text { ondotrae }\end{array}$ & Hirudinea \\
\hline CLBE-01 & 21 & 100 & 0 & 67 & 100 & 0 & 67 & 0 & 83 & 0 \\
\hline CLBE-02 & 37 & 0 & 0 & 100 & 80 & 0 & 40 & 0 & 40 & 0 \\
\hline CORE-01 & 12 & 25 & 0 & 0 & 11 & 0 & 11 & 11 & 0 & 0 \\
\hline CORE-02 & 10 & 75 & 20 & 55 & 0 & 0 & 0 & 11 & 0 & 0 \\
\hline DATR-01 & 0 & 0 & 0 & 60 & 100 & 0 & 80 & 80 & 0 & 0 \\
\hline DATR-02 & 0 & 0 & 20 & 40 & 60 & 0 & 60 & 20 & 0 & 0 \\
\hline DELA-01 & 0 & 0 & 0 & 20 & 40 & 80 & 80 & 40 & 40 & 11 \\
\hline DELA-02 & 7 & 75 & 0 & 11 & 44 & 44 & 11 & 77 & 0 & 0 \\
\hline DRLA-01 & 5 & 0 & 0 & 50 & 100 & 0 & 100 & 50 & 13 & 0 \\
\hline DRLA-02 & 22 & 0 & 20 & 50 & 75 & 0 & 83 & 91 & 0 & 0 \\
\hline ENBE-01 & 89 & 0 & 0 & 66 & 100 & 0 & 17 & 0 & 17 & 16 \\
\hline ENBE-02 & 77 & 0 & 0 & 29 & 100 & 0 & 43 & 0 & 29 & 0 \\
\hline ESLA-01 & 0 & 0 & 20 & 40 & 80 & 0 & 100 & 40 & 0 & 0 \\
\hline ESLA-02 & 0 & 0 & 20 & 100 & 40 & 0 & 0 & 20 & 0 & 0 \\
\hline FECA-01 & 1 & 0 & 0 & 13 & 88 & 0 & 38 & 38 & 0 & 0 \\
\hline FECA-02 & 1 & 0 & 0 & 100 & 100 & 0 & 0 & 40 & 0 & 0 \\
\hline OSTR-01 & 0 & 0 & 0 & 64 & 91 & 0 & 0 & 64 & 18 & 0 \\
\hline OSTR-02 & 24 & 0 & 0 & 77 & 77 & 0 & 11 & 44 & 0 & 0 \\
\hline RDCR-01 & 0 & 50 & 0 & 44 & 44 & 0 & 0 & 0 & 0 & 0 \\
\hline RDCR-02 & 1 & 0 & 0 & 100 & 66 & 0 & 0 & 17 & 17 & 0 \\
\hline LAEA-01 & 0 & 0 & 0 & 0 & 40 & 0 & 40 & 0 & 20 & 0 \\
\hline ELCR-02 & 0 & 0 & 0 & 0 & 0 & 0 & 0 & 0 & 0 & 0 \\
\hline URCR-01 & 1 & 0 & 0 & 29 & 57 & 0 & 71 & 0 & 0 & 0 \\
\hline Overall & & $11 / 38$ & $7 / 115$ & & & & & & & \\
\hline Prevalence & $12.5 \%$ & $43.5 \%$ & $6.1 \%$ & $47 \%$ & $66 \%$ & $5 \%$ & $33 \%$ & $31 \%$ & $7 \%$ & $1 \%$ \\
\hline
\end{tabular}


vibrant coloration and organs turgid to touch. TEM sections of liver revealed no viral particles. Moribund animals spent a large amount of their time swimming at the water's surface and in the water column. Because Rana aurora aurora tadpoles are generally cryptic, spending a majority of their time on the substratum, this behavior was unusual.

\section{Histopathological examination and identification of parasites}

Eight species of parasites, including fungi, protozoa, and trematodes were detected by histological examination of the integument, buccal cavity, and cloaca. Of the 38 tadpoles with visible gross oral disc abnormalities, 11 (29\%, $95 \% \mathrm{CI}=15-46 \%$ ) were confirmed on histological examination to be infected with Batrachochytrium dendrobatidis zoosporangia (Table 2). Of the 115 animals collected randomly, 7 (6.1\%, $95 \% \mathrm{CI}=2.6-12 \%$ ) were infected. This difference was statistically significant $\left(\chi^{2}=12.2613, \mathrm{df}=1, \mathrm{p}=0.0005\right)$. In animals infected with chytrid thalli, the normally thickly layered keratinized epithelial tissue was frequently either completely missing or degraded. However, in the 7 infected individuals that did not have observable gross depigmentation, Batrachochytrium dendrobatidis thalli were detected in darkly pigmented cells. Chytrid thalli were only present in the keratinized epithelial cells of the beak and toothrows. B. dendrobatidis was most commonly found infecting the anterior beak ( $83 \%$ of all the infected tadpoles), followed by toothrows (44\%), and posterior beak (22\%). Hyperkeratotic and acanthotic responses to chytrid infection were not seen in infected tadpoles. There was no difference in prevalence estimates between lotic and lentic habitats (Table 3).

Cottony material extruding from cloacae were identified by SEM examination as Epistylis sp. Epistylis sp. are colonial, sessile, peritrich ciliate protozoans with a long basal stalk and an inverted bell shaped body containing cilia surrounding the epistome (Hoffman 1999). Epistylis sp. was seen in $47 \%$ (95\% CI $=39-55 \%)$ of all tadpoles on $83 \%$ of pond sampling occasions.
Table 3. Rana aurora aurora. Repeated-measures ANOVA model comparing parasite intensities in tadpoles collected during 2 breeding years (2001 and 2002) and 2 habitats (lentic and lotic). Critical $\alpha=0.05$

\begin{tabular}{|c|c|c|c|c|}
\hline Parasite & Mean & MS & $F$-ratio & Probability \\
\hline \multicolumn{5}{|c|}{ Batrachochytrium dendrobatidis ${ }^{\mathrm{a}}$} \\
\hline \multicolumn{5}{|c|}{ Year } \\
\hline 2001 & 6.1 & 0.00531 & 0.35 & 0.56 \\
\hline 2002 & 8.1 & & & \\
\hline \multicolumn{5}{|l|}{ Habitat } \\
\hline Lentic & 8.2 & 0.01242 & 0.82 & 0.39 \\
\hline Lotic & 4.7 & & & \\
\hline Year $\times$ Habitat & & 0.02322 & 1.54 & 0.25 \\
\hline \multicolumn{5}{|l|}{ Apiosoma sp. } \\
\hline \multicolumn{5}{|l|}{ Year } \\
\hline 2001 & 254 & 23673 & 2.92 & 0.13 \\
\hline 2002 & 476 & & & \\
\hline \multicolumn{5}{|l|}{ Habitat } \\
\hline Lentic & 331 & 223056 & 27.48 & 0.004 \\
\hline Lotic & 92 & & & \\
\hline Year $\times$ Habitat & & 553 & 0.07 & 0.80 \\
\hline \multicolumn{5}{|l|}{ Trichodina sp. } \\
\hline \multicolumn{5}{|l|}{ Year } \\
\hline 2001 & 8.8 & 20.83 & 5.81 & 0.04 \\
\hline 2002 & 7.4 & & & \\
\hline \multicolumn{5}{|l|}{ Habitat } \\
\hline Lentic & 8.3 & 1.67 & 0.47 & 0.51 \\
\hline Lotic & 7.9 & & & \\
\hline Year $\times$ Habitat & & 3.79 & 1.06 & 0.33 \\
\hline \multicolumn{5}{|l|}{ Ribeiroia sp. } \\
\hline \multicolumn{5}{|l|}{ Year } \\
\hline 2001 & 5.0 & 0.43 & 2.05 & 0.19 \\
\hline 2002 & 0.5 & & & \\
\hline \multicolumn{5}{|l|}{ Habitat } \\
\hline Lentic & 3.0 & 0.25 & 1.20 & 0.30 \\
\hline Lotic & 2.5 & & & \\
\hline Year $\times$ Habitat & & 0.05 & 0.22 & 0.65 \\
\hline \multicolumn{5}{|c|}{ Gyrodactylus aurorae } \\
\hline \multicolumn{5}{|c|}{ Year } \\
\hline 2001 & 1.9 & 1.60 & 2.51 & 0.15 \\
\hline 2002 & 3.4 & & & \\
\hline \multicolumn{5}{|l|}{ Habitat } \\
\hline Lentic & 2.3 & 2.94 & 4.60 & 0.06 \\
\hline Lotic & 3.0 & & & \\
\hline Year $\times$ Habitat & & 1.91 & 2.99 & 0.12 \\
\hline${ }^{\mathrm{a}}$ prevalence, no & & & & \\
\hline
\end{tabular}

Three protozoan parasites were identified in histological sections of the tadpole oral discs examined. Apiosoma sp. (a peritrich ciliate) was the most common and occurred at the highest prevalence $(66 \%, 95 \% \mathrm{CI}$ $=58.7-72.8 \%$ ) and second highest intensity (240 cells tadpole $^{-1}$ ) of all parasites (Table 2). Apiosoma sp. was identified by its large triangular macronucleus and ciliated epistomal lip (Hoffman 1999). Apiosoma sp. was found at all but 2 ponds (91\%). They were observed colonizing external epidermal and rostral buccal epithelium but not caudal buccal epithelium. These ciliates occurred singly or in small groups and were characterized by few to many vacuoles in the anterior 
body. The squamous epithelial cells at the base of the scopula were often degraded and the ciliate emerged from the resultant divot. Apiosoma sp. were found in significantly higher intensities from lentic than lotic habitats ( $p=0.004$, Table 3 ) and were comparably abundant in the 2 years.

A second ciliate (Family Trichodinidae) was the second most abundant parasite $(33 \%, 95 \% \mathrm{CI}=26-40 \%)$; it was present on 16 of the sampling occasions (70\%) (Table 2). Trichodiniids were recognized in sections by the possession of cilia and chitinoid denticles on their aboral surface (Hoffman 1999, Wright \& Whittaker 2001). Trichodiniids were often observed on oral papillae of the tadpoles. These protozoans occurred at significantly higher intensities in samples collected during 2001 than in those collected in 2002 ( $p=0.04$, Table 3) but there was no significant difference between habitat types.

The flagellate Ichthyobodo sp. was observed in 5\% (95\% CI $=2.2-9.7 \%$ ) of the tadpoles examined from a single lentic location (DELA) in 2001 and 2002, and was not included in further statistical analysis. These distinctive biflagellated organisms infested the epithelium of the buccal cavity, and were either attached or unattached to epithelial tissue (Hoffman 1999). In about half of the cases, they occurred as very localized infections, while in the other half thousands of organisms occupied the majority of epithelial surface of the buccal cavity. In one case, the tissues surrounding the infected area were severely degraded and had multiple tears.

In addition to protozoa, 3 metazoan parasites were identified in the tadpoles. Epidermal cysts due to penetration by the digenetic trematode cercaria of Ribeiroia sp. (Wright \& Whittaker 2001) were frequently observed during external examination of tadpoles. Cysts of Ribeiroia sp. were found in moderately low prevalence $(6.7 \%, 95 \% \mathrm{CI}=3.5-12 \%)$ overall, and occurred at 8 of $23(35 \%)$ collection locations. The tadpoles that were colonized by Ribeiroia sp. had an aggregated distribution of the parasites within the host $(k=0.021)$; a majority of the individuals had 0-1 parasites, while a small number of infected tadpoles had $>1$ parasite.

A monogenean trematode (Gyrodactylus aurorae) was seen in $51(31 \%, 95 \%$ CI $=24-39 \%)$ tadpoles examined from $70 \%$ of sites. Trematodes were found attached to the epithelium of the buccal cavity as well as among external oral papillae. In some cases, worms were seen directly adjacent to other worms, a characteristic of reproductive behavior (Hoffman 1999). G. aurorae was identified by the hamuli (hooks or anchors) of the posterior organ surrounded by marginal hooklets (Hoffman 1999, Wright \& Whittaker 2001). G. aurorae intensities were not significantly different by year or habitat types (Table 3). Like Ribeiroia sp., G. aurorae had an aggregated distribution, with a low $k$-value $(k=0.062)$.

Two tadpoles were parasitized with leeches (Class Hirudinea) within the buccal cavity (Table 2). In each case, the leech was about $25 \%$ the size of the affected tadpole. The animals containing leeches were collected at 2 different sites (ENBE, DRLA), in which leeches were also collected in the dip-nets during sampling.

\section{Parasite community dynamics and chytridiomycosis.}

Tadpoles at all sites surveyed had some degree of parasitism, with most populations infected by multiple parasites (Table 2). Only one population (ELCR) was infected by a single parasite species (Epistylis sp.) and this population was surveyed only during the second year of the study. Five of the parasites (Apiosoma sp., Batrachochytrium dendrobatidis, Epistylis sp., Trichodinidae, and Gyrodactylus aurorae) were widespread throughout the populations surveyed, while the others (Ichthyobodo sp., and the leech) were less frequently enountered (Table 2). Statistically significant odds ratios (OR) were observed based on the logistic regression of chytridiomycosis, with the following risk factors: oral disc abnormality $(\mathrm{OR}=10.0, \mathrm{p}=0.002)$, morbidity $(\mathrm{OR}=0.8, \mathrm{p}=0.015), \mathrm{G}$. aurorae infection $(\mathrm{OR}=$ $0.1, \mathrm{p}=0.015)$, mean pond depth $(\mathrm{OR}=4.1, \mathrm{p}=0.019)$, and being from a lotic habitat $(\mathrm{OR}=6.8, \mathrm{p}=0.021)$. Mean pond depth for tadpoles with chytridiomycosis $(1.12 \mathrm{~m})$ was significantly greater than for tadpoles without chytridiomycosis $(0.91 \mathrm{~m}, \mathrm{p}=0.05)$.

Individual tadpoles were often infected by multiple parasites concurrently. Eighty-six percent of tadpoles surveyed had at least one parasite, while $63 \%$ were infected by more than one parasite species (Fig. 1). No tadpole bore $>5$ parasite species. From the 163 tadpoles examined, 5 of the 7 parasite taxa were found as infections concurrent with chytridiomycosis.

The degree of parasite diversity in individual tadpoles was significantly affected by the presence of Batrachochytrium dendrobatidis zoosporangia. B. dendrobatidis-infected animals had significantly fewer parasite species (lower species richness) than those not infected $($ mean infected $=1.11$, mean uninfected $=$ $1.99, \mathrm{p}=0.006)$. Because species richness is a simplified representation of species diversity that does not account for relative abundance, the Brillouin index of diversity was also used to compare parasite diversities between chytrid infected and uninfected individuals. There was, likewise, a lower mean parasite diversity in tadpoles with chytridiomycosis (mean Brillouin index of infected animals $=0.082$, mean of uninfected $=$ $0.172, p=0.045$ ). Although there was no significant dif- 


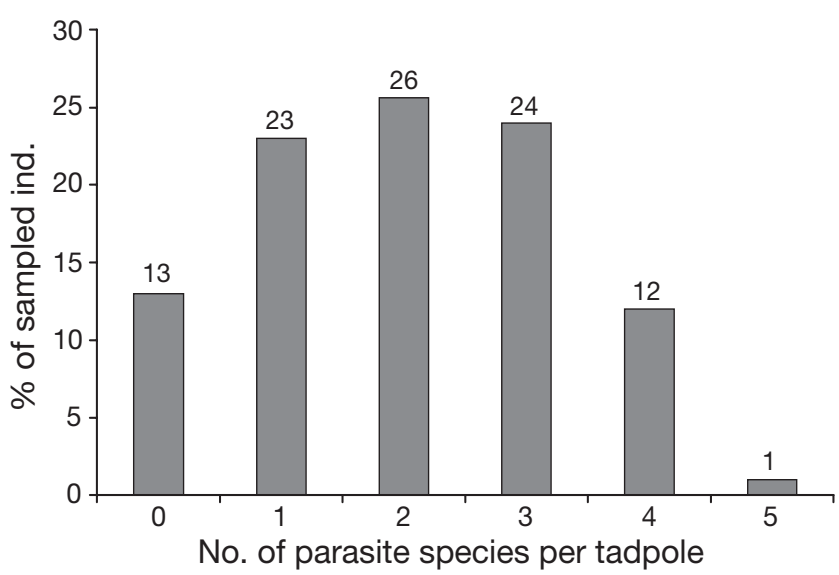

Fig. 1. Rana aurora aurora. Percentage of tadpoles infested by 0 to 5 different species of parasite (total $n=163$ )

ference in Brillouin indices between infected and uninfected tadpoles when Apiosoma sp. (the most widespread and abundant parasite species encountered) was removed from the analysis (mean Brillouin index of infected animals $=0.086$, mean of uninfected $=$ $0.144, \mathrm{p}=0.14$ ), the trend was consistent.

Total abundance of parasites may have influenced chytridiomycosis infection. Abundance was estimated by summing parasite species intensities for each individual tadpole and comparing between chytridiomycosis-infected and uninfected animals. Total parasite abundance and Apiosoma sp. abundance were both significantly higher in uninfected tadpoles than in Batrachochytrium dendrobatidis-infected tadpoles (mean total parasite abundance in infected tadpoles $=$ 78, mean total parasite abundance in uninfected tadpoles $=212, \mathrm{p}=0.006$; mean Apiosoma sp. abundance in infected tadpoles $=75.6$, mean Apiosoma sp. abundance in uninfected tadpoles $=167.8, \mathrm{p}=0.047$ ). When Apiosoma sp. was removed from the analysis there remained a significant difference between infected and uninfected groups (mean infected $=2.4$, mean uninfected $=43.9, p=0.03$ ), most likely due to the presence of Ichthyobodo sp. at high intensity in just a few of the tadpoles uninfected with $B$. dendrobatidis (mean intensity $=39.4$ ), but in none of the infected tadpoles. None of the other parasites analyzed individually had significantly different abundance estimates between infected and uninfected tadpoles.

\section{DISCUSSION}

Rana aurora aurora tadpoles in 13 ponds in and around Redwood National Park were infested with a diverse array of parasites, including Batrachochytrium dendrobatidis, flukes, leeches, and protozoa; importantly, chytridiomycosis was detected in some subclinical animals lacking oral disc lesions, and infection was associated with some environmental and co-infection risk factors. Gyrodactylus aurorae infection, shallower depth, lack of mouthpart lesions, and presentation with lesions characteristic of the morbidity event were associated with reduced risk of chytridiomycosis. In general, shallower depths have a tendency to be warmer, which may promote ciliate and fluke growth (Hoffman 1999). However, B. dendrobatidis grows better in culture at cooler temperatures (Piotrowski et al. 2004). Therefore, tadpoles in shallower water may experience higher temperatures and suffer or die from parasite infections other than $B$. dendrobatidis. Additionally, shallower ponds are more ephemeral, which would limit the maintenance of $B$. dendrobatidis in an overwintering reservoir host, thus limiting year to year transmission.

As expected, the odds of chytridiomycosis were much higher in animals with mouthpart lesions, but interestingly many infected tadpoles appeared to be subclinically infected. This may reflect a generally lower level of susceptibility in this frog species than in others, such as yellow-legged frogs (Fellers et al. 2001, Knapp \& Morgan 2006). Rana catesbeiana and Hyla regilla also have high survival rates when experimentally infected with chytridiomycosis (Blaustein et al. 2005). Alternatively, the discrepancy in lesions may also be due to Batrachochytrium dendrobatidis strain differences; however, this was not evalutated (Berger et al. 2005). Additionally, swollen, pinkish or reddish papillae characteristic of severe larval chytridiomycosis, as seen in R. muscosa (Fellers et al. 2001), did not occur in $R$. aurora aurora larvae. Nevertheless, the finding of infected frog larvae in the absence of overt disease may suggest a possible reservoir for infection, as well as an important target for future studies assessing levels of chytrid fungal infection in nature. The data were limited in this study to a single frog species and, potentially, to a single $B$. dendrobatidis strain from northern coastal California; future studies should be more comprehensive in assessing larvae and possibly subclinically-affected individuals. Also, although a majority of our tadpoles with chytridiomycosis had oral disc abnormalities, others have shown identical lesions as a result of very cold temperatures, with no evidence of chytrid infection (Rachowicz 2002, Rachowicz \& Vredenburg 2004). In this study, there were 38 tadpoles with lesions consistent with chytridiomycosis but in which no chytrid thalli were identified by microscopy. Overwintering and cold temperature could have caused similar lesions. Thus findings in this and other studies demonstrate that depigmentation of mouth structures is a screening tool only and must be 
combined with microscopy or PCR to fully evaluate prevalence of chytridiomycosis in a population; some proportion of apparently unaffected individuals should be examined as well.

The protozoan parasites that occurred singly or as coinfections with chytridiomycosis included Ichthyobodo sp., Trichodinidae, Epistylis sp., and Apiosoma $\mathrm{sp}$. These represent new host records for the northern red-legged frog and, in the case of Epistylis sp. and Apiosoma sp., new geographic reports for North America (Hoffman 1999). Even though no morbidity was associated with most of the protozoal pathogens detected, all have been reported to cause disease in fishes or other vertebrates. Both Apiosoma sp. and Epistylis sp. have low pathogenic potential but can overcrowd and block the gut tube and sometimes partially smother the gills (Hoffman 1999). In contrast, Ichthyobodo sp. and Trichodiniids are considered important pathogens of aquatic vertebrates (Hoffman 1999). Trichodina acuta was reported to induce mechanical injury and death in tadpoles and fish (Lom 1958). The flagellate species $I$. necator, which infects amphibian larvae, generally lacks host specificity and is very pathogenic (Hoffman 1999).

The ability of many pathogens to affect the distribution and colonization potential of others is an interesting phenomenon. Pathogen diversity was lower in animals infected with Batrachochytrium dendrobatidis. Apiosoma sp. abundance was lower in individual chytrid-infected tadpoles and accounted for a significant portion of the difference in Brillouin index differences between infected and uninfected tadpoles. There is thus good evidence for some interaction between Apiosoma sp. and chytrid infection of northern red-legged frog tadpoles. Several explanations for this interaction of chytrids with other parasites are possible. Commonly, parasites of vertebrates compete for resources within their host. Batrachochytrium dendrobatidis may exclude other parasites within the buccal cavity of the larval red-legged frog through either direct and/or indirect competitive interactions. Direct effects of chytrid fungus on the rest of the parasite fauna may include allelopathic secretions preventing other parasites from colonizing, competition for space within the buccal cavity of the frog, and direct consumption of other protozoa and metazoan parasites (i.e. predation). Indirect effects might be moderated by a host immune response that affects other parasites more than the chytrid fungus. Alternatively, a diverse parasite fauna may negatively influence the ability of $B$. dendrobatidis to infect tadpoles by the same means (allelopathy), through resource competition, or through direct consumption (predation), and/or by an indirect effect of the host immune system. Another possibility is that animals infected with both chytrid and other parasites do not survive and hence were not captured during the survey. Wild animals are often more reclusive when diseased and thus less likely to be encountered. Whatever its cause, the phenomenon warrants further investigation.

Both species of trematode and the leech identified in this study are common parasites of amphibians (Wright \& Whittaker 2001). Ribeiroia sp. causes limb malformations in many species of amphibians (Johnson et al. 2002), while Gyrodactylus spp. are mostly host specific (Hoffman 1999). Gyrodactylus spp. been identified from amphibians in California, infecting Ambystoma macrodactylum (G. ambystomae), Dicamptodon ensatus (G. ensatus), and red-legged frog larvae (G. aurorae) (Mizelle et al. 1968, 1969). Gyrodactylus spp. often cause damage by using hard tissue hooks to penetrate the epidermis, in many instances causing death. Both Ribeirioia sp. and G. aurorae identified in this study occurred at relatively low prevalence and intensity levels but were widespread. Although common parasites of adult amphibians, fish, birds and mammals, only 2 leeches were found in this study. No lesions were observed in association with any of the metazoan parasites identified.

Numerous unusual morbidity and mortality events have been described for amphibians in the recent past (Cunningham et al. 1996, Berger et al. 1998, Bollinger et al. 1999, Taylor et al. 1999a,b, Bradley et al. 2002, Green et al. 2002). Where characterized, the etiologies have involved either fungal, viral, or bacterial pathogens. For example, a study of unusual mortality in sympatric stickleback fish and red-legged frog larvae found the animals infected with viruses in the order Iridoviridae (Mao et al. 1999). Unfortunately, viral and bacterial pathogens could not be evaluated for the morbidity events observed in this study.

Parasites and morbidity in northern red-legged frog larvae were associated with environmental risk factors, including increased risk of chytridiomycosis at greater depths and in lotic habitats. Ciliates reportedly thrive in waters that are of poor quality for vertebrates and contain high host densities; these are often lentic habitats that are otherwise suitable for the health of individual animals (Hoffman 1999). In this study, Apiosoma sp. infestation was observed at significantly higher intensities in tadpoles collected from lentic habitats. Amphibian host defenses against parasites include innate and adaptive immunological response; these protective elements are less effective in larvae than in adults and are impaired under a variety of environmental stressors (Flajnik et al. 1987, Marx et al. 1987, Du Pasquier \& Flajnik 1990, Warburg et al. 1994, Austin 2000, Green 2001, Rollins-Smith et al. 2002a,b). We did not measure failure of adequate immune response, but the lack of detectable phagocytic cell 
infiltrate in any of the lesions observed is indicative of a compromised immune system. An additional source of environmental risk for tadpoles in this study could include the presence of coinfecting organisms and of other vertebrates that support such parasites. Given that cross-infection of viral and fungal pathogens between fish and amphibians does occur (Mao et al. 1999, Kiesecker et al. 2001), it is plausible that protozoal parasite intensity and prevalence could be influenced by the abundance and prevalence of infection in fish that are sympatric with Rana aurora aurora.

Tadpole morbidity is widespread in northern coastal California populations of northern red-legged frogs. Many protozoal and metazoan parasites are known to cause lesions when present in high abundance, but otherwise do not seem to affect the health of individual animals (Hoffman 1999). In general, studies of parasites in amphibian larvae have focused on one parasite species or have regarded the tadpole as a possible intermediate host for a more complex life cycle (Mizelle et al. 1969, Berger et al. 1998, Johnson et al. 2002). Future research should include more detailed descriptions of disease at the organismal and cellular levels as well as identification of ecological and morphological variables that may influence the prevalence of morbidity. In summary, these data contribute to our understanding of the ecology of chytridiomycosis and other parasitic diseases of amphibians in different types of habitat, highlighting interactions of environmental and infectious factors in subclinical as well as clinical, potentially lethal parasitism.

Acknowledgements. We thank G. Fellers and D. E. Green for providing initial details on the distribution and identification of chytridiomycosis in red-legged frogs; W. Bigg for help with logistic regression analysis; J. Bettaso, B. Exberger, and M. Gil for help in field collections; Drs. W. Brueske, R. Brown and F. Shaughnessy for essential insights in study design and implementation; and Redwood National Park for facilitating research in the park, and the Humboldt State Wildlife Disease Club and Humboldt Herpetology Research Group for providing valuable criticism of research design. Funding for this research was provided by the Department of Biological Sciences Master's Grant, Humboldt State University (HSU) and a RSCA grant from the Office of Research and Graduate Studies (HSU).

\section{LITERATURE CITED}

Austin R (2000) Cutaneous microbial flora and antibiosis in Plethadon ventralis: inferences for parental care in the Plethodontidae. In: Bruce R, Jaeger R, Houck L (eds) The biology of Plethodontid salamanders. Kluwer Academic/ Plenum Publishers, New York, p 451-462

Berger L, Speare R, Daszak P, Green DE and 10 others (1998) Chytridiomycosis causes amphibian mortality associated with population declines in the rain forests of Australia and Central America. Proc Natl Acad Sci USA 95: 9031-9036
Berger L, Marantelli G, Skerrat LF, Speare R (2005) Virulence of the amphibian chytrid fungus Batrachochytrium dendrobatidis varies with the strain. Dis Aquat Org 68:47-50

Blaustein AR, Johnson PTJ (2003) The compexity of deformed amphibians. Frontiers Ecol Environ 1:87-94

Blaustein AR, Hoffman PD, Hokit DG, Kiesecker JM, Walls SC, Hays JB (1994) UV repair and resistance to solar UV$\mathrm{B}$ in amphibian eggs - a link to population declines. Proc Natl Acad Sci USA 91:1791-1795

Blaustein AR, Romansic J, Scheessele E, Han B, Pessier AP, Longcore JE (2005) Interspecific variation in susceptibility of frog tadpoles to the pathogenic fungus Batrachochytrium dendrobatidis. Conserv Biol 19:1460-1468

Bollinger TK, Mao JH, Schock D, Brigham RM, Chinchar VG (1999) Pathology, isolation, and preliminary molecular characterization of a novel iridovirus from tiger salamanders in Saskatchewan. J Wildl Dis 35:413-429

Bradley GA, Rosen PC, Sredl MJ, Jones TR, Longcore JE (2002) Chytridiomycosis in native Arizona frogs. J Wildl Dis 38:206-212

Calef GW (1973) Natural mortality of tadpoles in a population of Rana aurora. Ecology 54:741-758

Carey C, Bradford D, Brunner J, Colins J and 5 others (2003) Biotic factors in amphibian population declines. In: Linder G, Krest S, Sparling D (eds) Amphibian decline: an integrated analysis of multiple stressor events. Society of Environmental Toxicology and Chemistry, Pensacola, FL, p 153-208

Chan-McLeod ACA (2003) Factors affecting the permeability of clearcuts to red-legged frogs. J Wildl Manag 67: 663-671

Cunningham A, Langton T, Bennett P, Lewin J, Drury S, Gough R, MacGregor S (1996) Pathological and microbiological findings from incidents of unusual mortality of the common frog (Rana temporaria). Phil Trans R Soc Lond B 351:1539-1557

Daszak P, Berger L, Cunningham AA, Hyatt AD, Green DE, Speare R (1999) Emerging infectious diseases and amphibian population declines. Emerg Infect Dis 5: 735-748

Davidson C, Shaffer HB, Jennings MR (2001) Declines of the California red-legged frog: climate, UV-B, habitat, and pesticide hypotheses. Ecol Appl 11:464-479

Davidson C, Shaffer HB, Jennings MR (2002) Spatial tests of the pesticide drift, habitat destruction, UV-B and climate change hypotheses for Californian amphibian population declines. Conserv Biol 16:1588-1601

Du Pasquier L, Flajnik M (1990) Expression of MHC class II antigens during Xenopus development. Dev Immunol 1:85-95

Duellman WE, Trueb L (1986) Biology of amphibians. Johns Hopkins University, Baltimore, MD

Fellers GM, Green DE, Longcore JE (2001) Oral chytridiomycosis in the mountain yellow-legged frog (Rana muscosa). Copeia 2001 (4):945-953

Flajnik M, Hsu E, Kaufman J, Du Pasquier L (1987) Changes in the immune system during metamorphosis of Xenopus. Immunol Today 8:58-64

Goater CP (1994) Growth and survival of postmetamorphic toads - interactions among larval history, density, and parasitism. Ecology 75:2264-2274

Goater CP, Vandenbos RE (1997) Effects of larval history and lungworm infection on the growth and survival of juvenile wood frogs (Rana sylvatica). Herpetologica 53:331-338

Green DE (2001) Pathology of amphibia. In: Wright KM, Whittaker BR (eds) Amphibian medicine and captive husbandry. Krieger Publishing Company, Malabar, FL, p 401-485 
Green DE, Converse KA, Schrader AK (2002) Epizootiology of sixty-four amphibian morbidity and mortality events in the USA, 1996-2001. Ann NY Acad Sci 969:323-339

Hoffman GL (1999) Parasites of North American freshwater fishes. Comstock Publishing, Ithaca, NY

Humason GL (1979) Animal tissue techniques. WH Freeman, San Fransico, CA

Johnson PTJ, Lunde KB, Thurman EM, Ritchie EG and 6 others (2002) Parasite (Ribeiroia ondatrae) infection linked to amphibian malformations in the western United States. Ecol Monogr 72:151-168

Kiesecker JM (2002) Synergism between trematode infection and pesticide exposure: a link to amphibian limb deformities in nature? Proc Natl Acad Sci USA 99:9900-9904

Kiesecker JM, Blaustein AR, Miller CL (2001) Transfer of a pathogen from fish to amphibians. Conserv Biol 15: 1064-1070

Knapp R, Morgan JA (2006) Tadpole mouthpart depigmentation as an accurate indicator of chytridiomycosis, an emerging disease of amphibians. Copeia 2006 (2):188-197

Licht LE (1971) Breeding habits and embryonic thermal requirements of the frogs Rana aurora aurora and Rana pretiosa pretiosa, in the Pacific Northwest. Ecology 52: $116-124$

Lom J (1958) A contribution to the systematics and morphology of endoparasitic trichodinids from amphibians, with a proposal of uniform specific characteristics. J Protozool 5: 251-263

Mao J, Green DE, Fellers GM, Chinchar VG (1999) Molecular characterization of iridoviruses isolated from sympatric amphibians and fish. Virus Res 63:45-52

Marx M, Ruben L, Nobis C, Duffy D (1987) Compromised Tcell regulatory functions during anuran metamorphosis: the role of corticosteroids. Dev Comp Immunol 1987: $129-140$

Mizelle J, Kritsky D, Bury R (1968) Studies on monogenetic trematodes. XLI. Gyrodactylus ensatus sp. n., the first species of the genus described from the amphibia. J Parasitol 54:281-282

Mizelle J, Kritsky D, McDougal H (1969) Studies of mongenetic trematodes. XXLII. New species of Gyrodactylus from amphibia. J Parasitol 55:740-741

Noss RF (2000) The redwood forest, history, ecology, and conservation of the coast redwoods. Island Press, Washington, DC

Editorial responsibility: Alex Hyatt, Geelong, Victoria, Australia
Pahkala M, Rasanen K, Laurila A, Johanson U, Bjorn LO, Merila J (2002) Lethal and sublethal effects of UV-B/pH synergism on common frog embryos. Conserv Biol 16: 1063-1073

Parris MJ, Baud DR (2004) Interactive effects of a heavy metal and chytridiomycosis on Gray Treefrog larvae (Hyla chrysoscelis). Copeia 2004 (2):344-350

Piotrowski J, Annis SL, Longcore JE (2004) Physiology of Batrachchytrium dendrobatidis, a chytrid pathogen of amphibians. Mycologia 96:9-15

Rachowicz LJ (2002) Mouthpart depigmentation in Rana muscosa tadpoles: seasonal changes without chytridiomycosis. Herpetol Rev 33:263-265

Rachowicz LJ, Vredenburg VT (2004) Transmission of Batrachochytrium dendrobatidis within and between amphibian life stages. Dis Aquat Org 61:75-83

Rollins-Smith LA, Carey C, Longcore J, Doersam JK, Boutte A, Bruzgal JE, Conlon JM (2002a) Activity of antimicrobial skin peptides from ranid frogs against Batrachochytrium dendrobatidis, the chytrid fungus associated with global amphibian declines. Dev Comp Immunol 26:471-479

Rollins-Smith LA, Doersam JK, Longcore JE, Taylor SK, Shamblin JC, Carey C, Zasloff MA (2002b) Antimicrobial peptide defenses against pathogens associated with global amphibian declines. Dev Comp Immunol 26:63-72

Shaw DJ, Grenfell BT, Dobson AP (1998) Patterns of macroparasite abundance and aggregation in wildlife host populations. Parsitology 117:597-610

Stebbins RC (2003) A field guide to western reptiles and amphibians. Houghton Mifflin, New York

Taylor SK, Williams ES, Mills KW (1999a) Mortality of captive Canadian toads from Basidiobolus ranarum mycotic dermatitis. J Wildl Dis 35:64-69

Taylor SK, Williams ES, Thorne ET, Mills KW, Withers DI, Pier AC (1999b) Causes of mortality of the Wyoming toad. J Wildl Dis 35:49-57

Warburg M, Lewinson D, Rosenburg M (1994) Ontogenesis of amphibian epidermis. In: Heatwole $\mathrm{H}$, Barthalmus GT (eds) Amphibian biology, Vol 1. The Integument. Surrey Beatty \& Sons, Sydney, p 33-63

Wright KM, Whittaker BR (eds) (2001) Amphibian medicine and captive husbandry. Krieger Publishing, Malabar, FL

Young BE, Lips KR, Reaser JK, Ibanez R and 10 others (2001) Population declines and priorities for amphibian conservation in Latin America. Conserv Biol 15:1213-1223

Submitted: June 27, 2006; Accepted: July 25, 2007

Proofs received from author(s): September 26, 2007 